\title{
Responding to Challenge: Comparing Nonprofit Programmes and Pedagogy at Universities in the United Kingdom, Spain and the United States ${ }^{1}$
}

\author{
Alex Murdock, Rebecca Tekula, Carmen Parra
}

\begin{abstract}
As the public sectors of many countries come to terms with the implications of major challenges, from reduced budgets and changes in the nature of public-sector employment, it is appropriate to reflect on the nature of nonprofit education and consider it in the context of management and business education in the public and private sectors. Until now, published research on nonprofit programmes in higher education has typically been focused on individual countries or types of programmes. This paper reviews the background of management education and compares university-level nonprofit education in the United Kingdom, Spain and the United States. We find that the number and types of academic programmes offered are aligned with both the size of the sector and the sector function in each country.
\end{abstract}

\section{Introduction}

Comparisons have been made between the nature and focus of nonprofit activity within different countries. In the United Kingdom, the Johns Hopkins studies are now familiar to researchers, and in Europe we have seen the emergence of research networks such as EMES and EURICE. There is also an emerging literature in social enterprise and social entrepreneurship, which has an increasingly international and comparative focus. Until now, published research on nonprofit programmes in higher education has typically been focused on individual countries or types of programmes (Mottner and Wymer 2011, Dolch et al. 2007, Young 1999). Variations in the nature of the nonprofit sector in different countries may arguably be associated

1 John Casey and Tom Lyons (both from the School of Public Affairs, Baruch College, City University of New York) contributed to this article. We would like to thank Pace University student, Jordan Jhamb, for his research assistance. 
with different patterns of development of educational programmes. This may affect content, forms of delivery and pedagogy.

The United States has seen the emergence of social entrepreneurship as a focus in educational programmes, which has influenced a number of university programmes. In the UK the pattern has been more towards the concept of "civil society", and there is a dearth of master-level programmes with a pure focus on social enterprise or social entrepreneurship. In Europe, the focus on the social economy and co-operatives has influenced programmes at the university level, and indeed the term "social economy" is explicit in both the title and the ethos of many such university programmes for the nonprofit sector.

To what extent do these differences represent real differences in the content, delivery and pedagogy of the programmes at the universities in the three different countries of comparison: UK, US and Spain? Are there, in fact, underlying differences in course and programme labels and apparent national differences or significant areas of similarity? This paper will make a contribution to understanding differences and similarities between university-level nonprofit education in the three countries involved in the study. As such it will contribute to understanding the possible future direction of nonprofit education in a world which has already become "global" with respect to business education and which arguably may become more international with regard to nonprofit education (O’Neill 2007).

As the public sectors of many countries come to terms with the implications of major challenges from reduced budgets and changes in the nature of public-sector employment, it is appropriate to reflect on the nature of nonprofit education and consider it in the context of management and business education in the public and private sectors.

\subsection{Emerging themes}

A number of themes have emerged which we endeavour to explore in this paper. One theme which the EGPA work ${ }^{2}$ has picked out is the issue of how management programmes vary across different sectors and in particular how the particular master's degrees compare across different dimensions: the MBA, the MPA and the various masters in nonprofit and social entrepreneurship. A second theme are the forms in which education is delivered. The traditional classroom context has now seen the emergence of forms of distributed learning. This is not a new phenomenon, and "distance learning" has been around for many years. However, it has grown rapidly in recent times and organisations like the University of Phoenix represent, in terms of student numbers, a major player in the business-education marketplace in the

2 The Permanent Study Group IX on "Public Administration and Teaching" (PSG IX) of the European Group of Public Administration (EGPA) has for several years discussed and compared contents and structures of academic degree programmes in public administration and nonprofit management. 
USA. In the UK the Open University occupies a similar prominence (accompanied by a research status not sought or enjoyed by its American counterpart). However, this development in conventional business education has not perhaps been mirrored in public administration and nonprofit programmes.

A third theme is found in the actual pedagogy. The MBA format has become closely linked with the use of a particular methodology: that of case studies. This approach originated in the USA at Harvard Business School. However it has become widely adopted in the UK and in continental Europe, and there is now an institutional structure in the form of "case clearing houses" with growing repositories of business cases. Though other pedagogies are emerging, the strong association of business cases with the MBA is well established. In the MPA context there have been some attempts to follow the MBA path: MPA-teaching often makes use of case studies. There is a growing inventory of case studies in both the North American and Anglo-European contexts. However, such case studies tend not to travel as well as their business equivalents. The challenges confronting a North American airline find resonance for MBA students in the UK or Spain as the issues and lessons have much in common. The public-management situation of an American hospital may not have the same transferability to the British National Health Service setting or indeed to that of a Spanish hospital. In the context of the nonprofit and social entrepreneurship context the use of case studies is a factor. These often may exhibit the motivation and drive of social entrepreneurs. The situation of nonprofits have also found some resonance in case studies which, like their business and publicsector counterparts, seek to demonstrate the issues confronting such organisations and how they rise (or fail) to meet challenges. However, both public and nonprofit pedagogy typically share a perceived need to communicate or foster a sense of value or social mission. This may be found in some business programmes (especially after observations of the lack of such values displayed by key figures in the sector).

There is also a fourth theme: the extent to which the various sector programmes are international in nature. The MBA programme has a strong claim to this with students travelling to study in different countries and the curriculum often having a similar international focus. The MPA programmes by their nature tend to be more localised within a country or sometimes even more narrowly within a region of the country. The particular legal and political aspects of the public sector perhaps limit the transferability of learning outcomes. The nonprofit programmes share aspects of the MPA in terms of a social mission and public-value orientation but arguably have the potential to reach across national boundaries. International nonprofits, by nature, work in more than one country, and the innovations and drive of social entrepreneurs are not constrained by political frontiers. 


\section{Background on management education}

In international terms, Management Education has a long history. Though in the USA it has predated World War II, in the UK the MBA programme is relatively recent in origin, and indeed at least one practicing academic at LSBU graduated from the very first class of the London Business School. ${ }^{3}$ In light of recent history, management education perhaps needs to take heed of the past criticism of such programmes. The following observation by Henry Mintzberg is particularly pertinent: "Conventional MBA programmes train the wrong people in the wrong ways with the wrong consequences" (Mintzberg 2004, 6).

We believe that the observations made by Murdock (2009) are still relevant to the MBA as a standardised product furnishing a generalisable qualification. Standardisation tends to be promoted via the presence of better accreditation bodies such the UK Association of Business Schools and, in the more international context, the Association of MBAs (AMBA). "The MBA is essentially a generalist qualification designed to widen the horizons of business professionals. It takes into account all the major functions and practises of a business" (AMBA 2009). Similarly, Murdock (2009) noted that the MPA as a public-sector companion to the MBA has also had a long history with the emergence of the MPA programmes. However, the accreditation history outside of the USA has been less clear. In the UK several MPA programmes have sought (and obtained) AMBA accreditation - usually where there is also an accredited MBA programme at the same institution. The MPA model significantly differs from that of the MBA, whereas it possesses a stronger focus upon discipline areas such as public policy and the political process.

The following table (Table 1) compares MBA/MPA/nonprofit programmes. It reflects the emergence of a new type of master's programmes (Master in Management) which has seen considerable growth in the UK. In effect this deals with the student demand for a management master which does not require the level of work experience of the MBA and which furnishes a generic management education perhaps for students recently graduated from an undergraduate degree.

\subsection{Literature review}

This paper builds on the comparative approach developed at the annual meeting of PSG IX of EGPA in 2009 (Murdock 2009) and continued in 2010 (Murdock and Oldfield). It also draws on work in the US which has recently led to two special editions of sector-relevant journals. (Academy for Management Learning and Education 2012(3), September 2012; Nonprofit Management and Leadership 23(1), Fall 2012).

3 Indeed one of the authors of this article (Murdock) graduated from a class (1987) of the London Business School where the MBA was an alternative option to the M.Sc. Only one student in that class opted for the M.Sc. - perhaps marking the formal arrival of the MBA as the preferred Management qualification. 


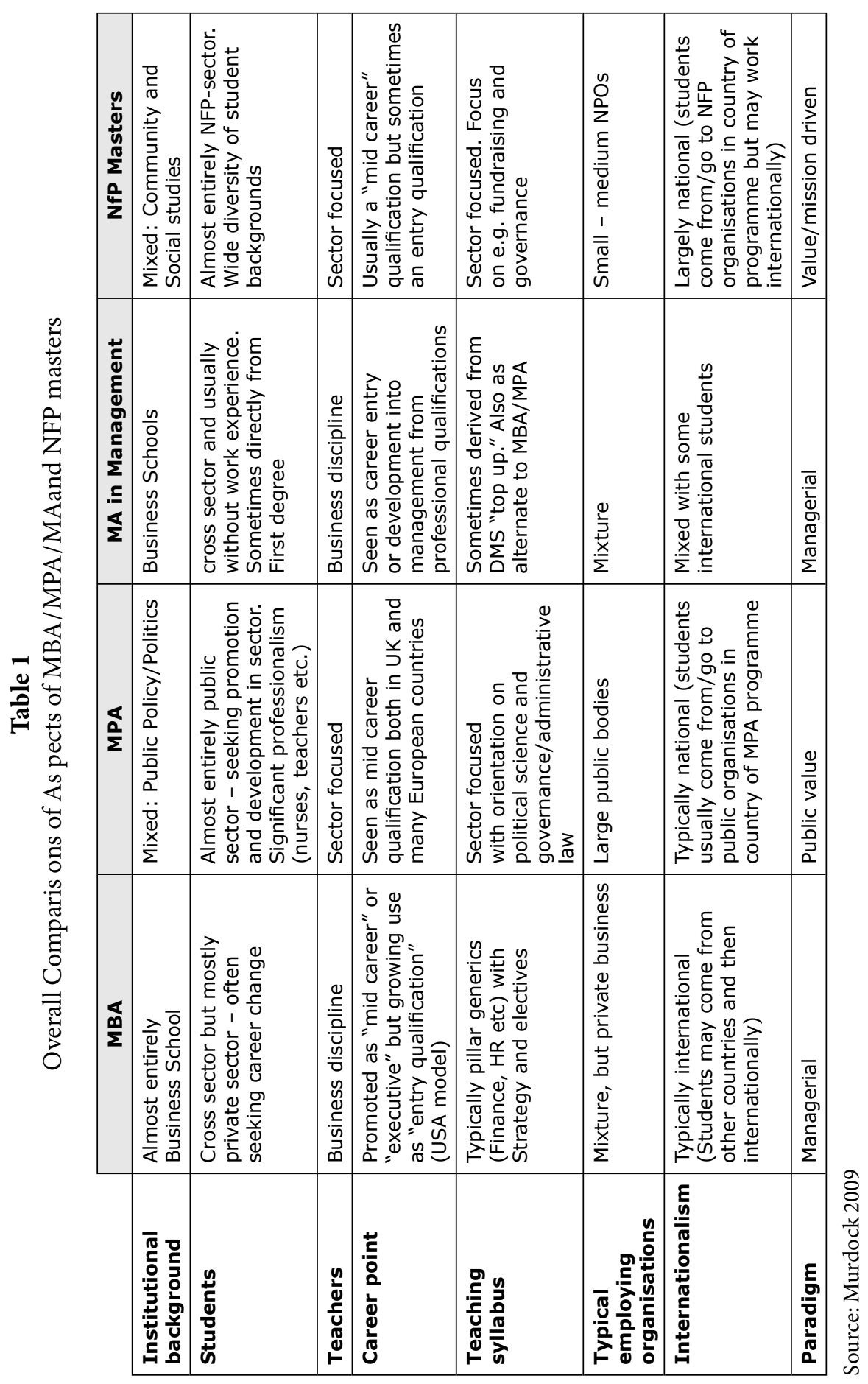


In a paper presented at the EGPA-PSG session in 2009, Murdock noted that the "MBA field has no lack of work assessing its contribution to education and is the subject of considerable attention in journals such as the Journal of Management Education. The Public and Third Sector has also received much attention with recent issues (or supplements) of journals having a particular issue focused on the subject. In 2007 the nonprofit area was a focus of a supplement to Nonprofit and Voluntary Sector Quarterly and in 2008 the International Journal of Public Sector Management also had a focused issue" (Murdock 2009).

At that point it was suggested that this was indicative of a degree of separation in the pedagogy of the three sectors and Murdock (based on a primarily UK-based database) drew attention to the dominance of MBA programmes over MPA or Third-Sector masters. In developing this work further we examine the development of social economy and social enterprise/entrepreneurial education in the USA, in the UK and in Spain. We posit that there are both similarities and differences that distinguish the operation of education in the different countries. We note the development of programmes such as the MBA and MPA, which to an extent represent an international dimension in Management education. From the data gathered from the previously mentioned EGPA comparisons on public administration education, we would highlight the following broader management concepts (i.e. issues which reach beyond public administration and potentially represent a common agenda with the other sectors of management and business education). For each concept we discuss the "crossover implications" which we believe can be identified.

a. The similarities in pedagogy and content across management programmes with common ground found in areas such as performance, change management, and leadership

Several papers evidenced this even though their focus may not have been so intended. Walsh (2006) described the importance of case studies, which are a standard tool in wider management education (the Harvard approach). Mikulowski (2008) notes that a number of students are taking the PA programmes in Poland in order to get work outside the public sector - implying a crossover based on the perceived transferability of learning. In a detailed study, Cepiku (2008) identifies areas of content in programmes in Italy which have considerable crossover potential (see also Van der Meer 2008, Matei 2009 and Kotchegura 2009). Accreditation of such programmes is often common to both public administration and other management programmes (AMBA has started to accredit MPA programmes, for example). The importance of credit transfer, transferability and comparability means that programmes exist in a wider domain. A bachelor's or master's degree is increasingly similar in certain respects, regardless of whether it is "sector specific".

b. Convergence of programmes and increasingly "trans-national" harmonisation in programme content and pedagogy 
Though the "EU" with its associated regulatory aspects is a factor in such convergence, it is not the only factor. Norell $(2008,2009)$ has an interesting perspective of running a truly transnational MPA programme (Norway and Sweden). He identifies the importance of "challenging the status quo" whilst functioning in a "trans-national setting". Perhaps significantly, one of the partners is in the $\mathrm{EU}$ and the other is not. Other papers make reference to the importance of "globalism" in MPA education including Walsh (2006), Mikulowski (2008), Cepiku (2008).

c. Issues of cultural, ethnic, gender, national and linguistic identity and difference It could be argued (and indeed some authors do) that these issues mark out the "public administration and public management" domain from, for example, the private sector. In parallel, it can be proposed that these areas are to be found in management generally. In the private (commercial) setting they may have a profit focus on customers, products and services whereas in the public sector they might be linked to employee issues and concepts of equality (see Oldfield 2007, Kolnishenko and Rosenbaum 2007, and Kiisla 2009). Perhaps it is an area where there has been a "crossover" from the public sphere, and increasingly issues of identity are generally found across management education.

d. The growth of "competence based" approaches and importance of practical application as well as theory

The stress of several papers has been on the challenge to provide "practical" knowledge as well as theory to students who are less accepting of just receiving the latter (Van der Meer 2008, Matei 2009, Van der Meer and Ringeling 2007). This applies particularly to management programmes. The stress upon acquisition of practical and applicable skills is shared by students and employers. This links to the next point in terms of the transfer and transferability of knowledge (Mikulowski 2009).

e. Knowledge and learning transfer with the importance of both a positive and "challenging" setting

The concept of knowledge and both receptivity and challenge was particularly highlighted by Broucker (2007). In their 2008 paper Broucker et al. draw attention to barriers to "crossover" within the public-sector sphere and regard this as a particular challenge to be addressed. Broucker and Hondeghem (2006) set up in another interesting paper a way to look at concepts of learning transfer. This paper, though directed at public-management education, is equally applicable to all management programmes. Indeed they highlight the need to include "nonpublic" sectors in learning transfer.

f. The move away from Legalistic to Managerial approaches in Public Administration 
A number of papers, especially those from transition countries and Southern Europe, draw attention to the traditional dimension of public administration as rooted (in educational terms) in law and administration as opposed to management and economics. The message emerging from these papers is that public administration - with help from EU harmonisation - is moving towards the academic disciplines of economics and management (Nemec et al. 2009, Esteves and Alvares 2006, Matei 2009, Cepiku and Meneguzzo 2007). The obvious point here is that these disciplines are more open to "crossover" with broader management programmes and education.

g. The concepts of "ethos and value" - linked to "professionalism"

There are a number of papers which focus on the concepts of public-sector "ethos and values", including Lethbridge (2009), Schroeter and Maravic (2007) and Quinn (2009). These papers variously identify and sometimes challenge the concept that there is a "public service ethos". The linkage which can be made between "values" and "professionalism" is worth exploring. This especially happens in one paper (Schroeter and Maravic 2007). The increasing aspiration of management to achieve "professional" standing is marked by the growth of professional bodies such as the Chartered Management Institute in the UK. The recent history of private-sector failure has seen movements towards a set of "values" for managers.

The public sector cannot argue that it is the repository of public value in an environment when public services are significantly delivered by private or not-for-profit organisations. The complexity of providers and funders suggests that the traditional separation of sectors may be eroded. If so, then the concept of ethos and value may be associated more with the nature of the service than with who furnishes it.

\section{Comparative analysis}

In this section we compare university-level nonprofit education and related programmes in the United Kingdom, Spain and the United States. Where available, we examine both the number and types of academic programmes on offer, in order to understand whether education is aligned with both the size of the sector and the sector function in each country.

As detailed in Table 2 below, the US nonprofit or third sector is, as expected, quite large when compared to that of Spain or the UK, employing roughly $10 \%$ of the workforce (Salamon et al. 2013) in over 2,000,000 institutions (Roeger et al. 2012). Meanwhile, the UK's third sector employs just over $2.2 \%$ of the workforce (UK Treasury 2007) with approximately 800,000 institutions (NCVO 2012). Spain's third sector is the smallest of the three countries in institutional terms, yet it 


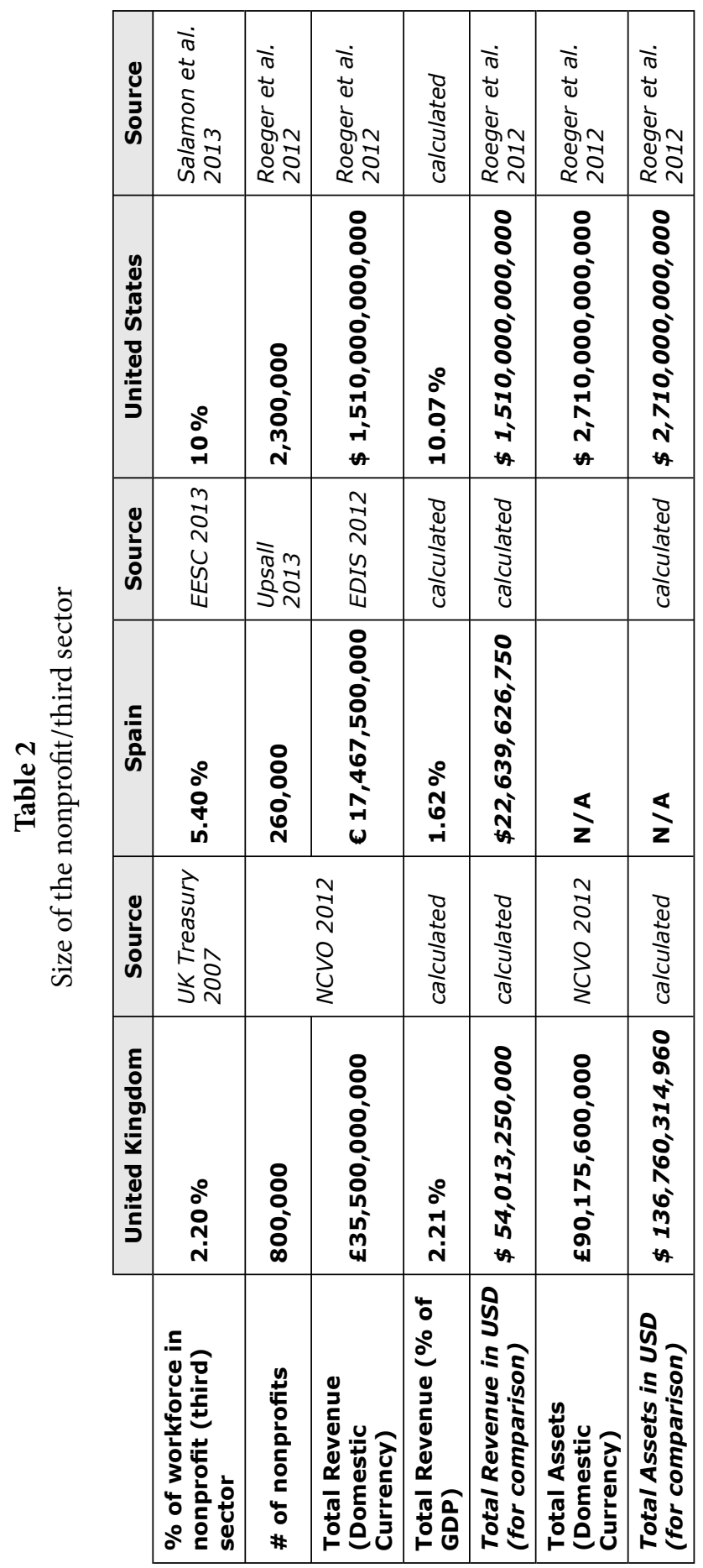




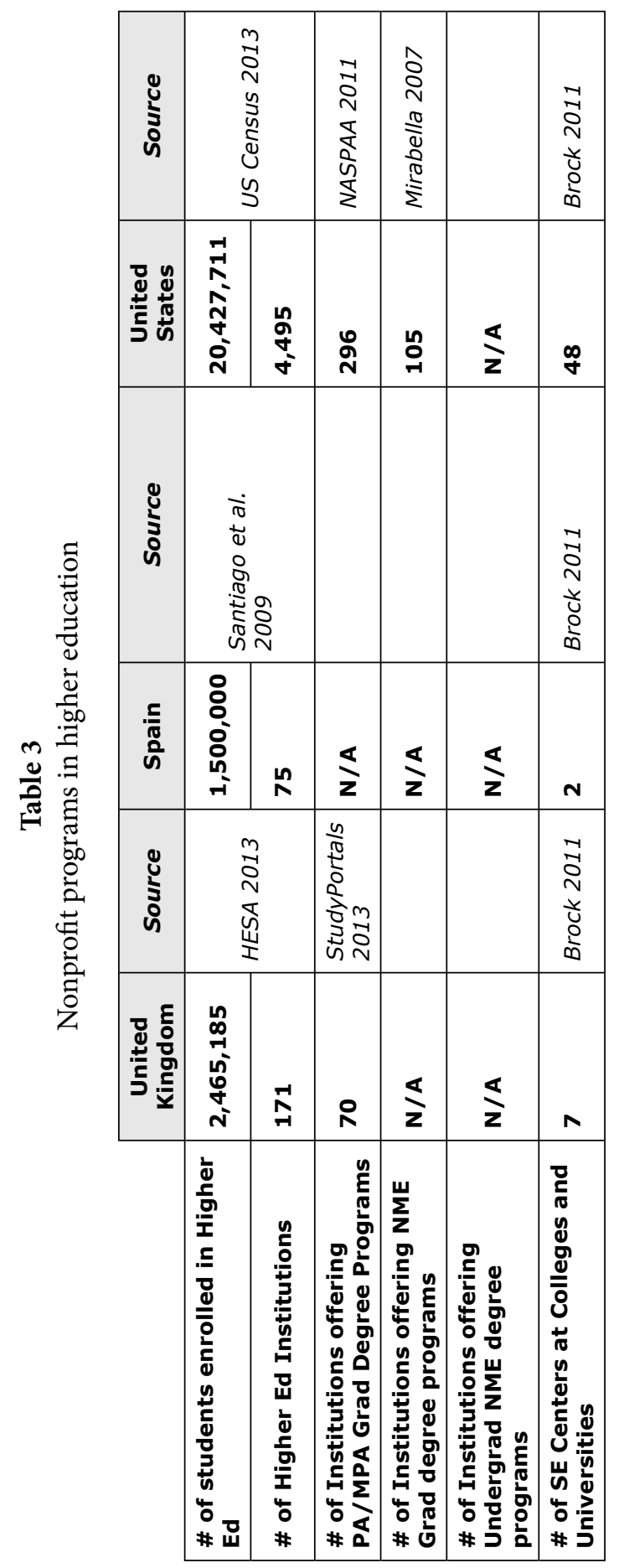


employs a relatively large $5.4 \%$ of the workforce (EESC 2013), with approximately 260,000 institutions (Upsall 2013).

\subsection{The case of the United Kingdom}

As with the MPA education there has been a specific journal issue focused on the not-for-profit sector, namely the Nonprofit and Voluntary Sector Quarterly 36(4) (Supplement). As with the MBA and MPA programmes discussed above the USA is regarded by some as the originator of the genre (Mirabella 2007).

O’Neill (2007, 169S), who provided a keynote address on the above-mentioned issue, confidently assured the readership:

- that the field (nonprofit management education) is here to stay;

- that it would not lead to an MBA style standardisation;

- that it would spread to bachelor's and Ph.D. degrees;

- that major foundation funding would be replaced by other external funding;

- that there would be a continuing albeit slower growth;

A search on a commonly used search engine for master's programmes (Findamasters.com) showed a divided and somewhat limited market. This can be described as follows:

- Social Entrepreneurship Masters: about four such programmes across the UK;

- Social Enterprise Masters: Only one;

- Charity-orientated programmes: Approximately four ${ }^{4}$;

- Voluntary/nonprofit sector programmes: Approximately four.

There is also evidence on the "findamasters.com" that the terms "social enterprise" and "social entrepreneurship" are widely found in a range of programmes (MBA, MPA etc.) as an element or module within the programme. The number of such programmes is considerable (approximately 100). These encompass mainly MBA and MPA programmes, along with a variety of others.

The case, however, is that the nature of the nonprofit sector, especially in the UK, is highly diverse. Many organisations are very small - often employing no staff at all. Some are highly business-like, drawing the majority of their income from trading, and the new legal category of Community Interest Company has been created to cater to such entities. Some could arguably be considered quasi-public in that they derive almost all their income from the provision of public services at the behest (some would argue the direction) of the state.

The presence of the nonprofit sector in a range of courses in business and public management suggests that managerial education in the sector is open to invasion from both the MBA and MPA providers. The MBA provider can focus on those who

4 The titles of the programmes indicate the main focus. 
operate a more business-focused model. The MPA provider could assert relevance for those engaged heavily in public-service delivery (or even those who campaign on policy issues). In return the not-for-profit-sector education can offer a focused approach to the organisational nature of the sector (insecurities of funding, values and mission-driven). The importance of a moral compass has been shown by Herman and Renz in a study of alumni of a USA nonprofit programme (Herman and Renz 2007).

A key difference - in UK educational terms - is that there are few undergraduate offerings with a nonprofit focus in the UK. This is quite significant when a comparison is made with, for example, the provision of business undergraduate programmes (over $15 \%$ of UK undergraduate courses). In May 2009, a search of the database of UK undergraduate degrees looked for nonprofit specific terms in the course description in addition to the course title (Murdock 2009). The results are shown in Table 4 below.

\section{Table 4}

Undergraduate courses (UK) per UCAS database

\begin{tabular}{|l|c|c|}
\hline \multicolumn{1}{|c|}{ Search Term } & 2009 course start & 2010 course start \\
\hline Charity & 0 & 0 \\
\hline Voluntary & 6 & 6 \\
\hline Non Profit (or Third Sector) & 0 & 0 \\
\hline Social Enterprise & 40 & 42 \\
\hline Citizenship & 35 & 28 \\
\hline Civil Society & 0 & 0 \\
\hline
\end{tabular}

Source: UCAS database

What was notable was that "social enterprise" appears to have acquired significant prominence ${ }^{5}$ - possibly through its incorporation in a number of business degrees. However, there do not appear to be any significant number of nonprofit/voluntary/charity-sector undergraduate programmes.

Meijs and Brudney (2007) explored at Erasmus University Rotterdam whether the third sector was significantly incorporated in undergraduate business programmes. Their findings suggest that there is very limited reference and what there is usually occurs in course units such as business ethics.

Perhaps one of the more thoughtful contributions to the debate on the issues of nonprofit education was made by Paton and his colleagues at the Open Univer-

5 A significant majority of these references are due to one institution, the University of Northampton, and at the time of access this reflected a relatively small number of actual students. It was the number of courses incorporating social enterprise. 
sity in the UK (Paton et al. 2007). They argue that nonprofit management education is "in product life cycle terms" rapidly ageing. They identify three trends which highlight this involving:

- changes in and around nonprofit organisations;

- changes on the demand and thinking of their managers;

- changes in the ways people learn and develop.

They note that management-education provision has grown for the sector in the UK but that there is a limited number of master-level programmes - much of the offer is in the form of short courses which are often not accredited. The changes in the sector towards public-service delivery and in the move away from grant to contract-funding is also a factor. However it is worth mentioning that the majority of not-for-profit ("charity") organisations in the UK function without contracts and indeed without a reliance on public funding.

Nevertheless the situation with master-level provision in the nonprofit and social-entrepreneurial sector in the UK is not a comfortable one. The cost of such courses represents a major impediment for small organisations and indeed for individuals. There is not the same increased income potential to recoup the investment, and often with small organisations there is a major problem in clearing time to attend. Paton et al. (2007) draw attention to the need for new forms of learning (distance and blended) which can address both this and the geographic problems of large areas of the country where there is no provider university within easy reach. However the set-up costs of distance learning provision is considerable and the relatively specialised nature of nonprofit programmes makes this hard to recoup in the short term.

Finally there is a provider issue universities (in the UK) typically set a minimum number of students for a course to run. For a two-year master's programme that number is about 15 - often more. The specialist nature of nonprofit programmes means that there is a limited potential to "share units" with other courses. However, the history of sector courses in the UK is replete with examples of courses being closed (as was the London School of Economics one) or being merged into what are perceived to be "similar" programmes in order to achieve more viable numbers.

The organisations which students work for are often highly vulnerable to changes in funding - making the students more likely to interrupt studies as they have to seek alternative employment or, as often, work longer to cover for colleagues who have left and cannot be replaced. Where, as is often the case with small organisations, the student is also the CEO, that student is highly vulnerable as there is no senior employed manager to argue their case with. This has led some to argue that nonprofit education is too important and too vulnerable to be left to market forces. In short either the state or some other external funder has to step in and furnish assurance to underpin the courses offered (Donnelly-Cox and McGee 2007). 
Other evolutions in the UK context have been the development of distance learning and "blended learning" programmes for the sector at both undergraduate and postgraduate levels. London South Bank University has developed an extensive postgraduate offer, and Anglia Ruskin University in Essex has an undergraduate offer. The limited focused provision may make these developments important. Finally there is the presence of educational providers who do not offer formal qualifications. Prominent amongst these are the School of Social Entrepreneurs which offers a focused programme on over a dozen sites around the UK and has also started to expand abroad (SSE 2012).

\subsection{The case of Spain}

Third-sector education in Spain is less evolved than in the UK or the USA. The model is orientated around the Southern European concept of the social or solidarity economy as opposed to the social enterprise or social entrepreneurial models in the Anglo Saxon or US setting.

Spain has a long and complex background with tensions still from the role of the state and church and a background of issues around civil liberties. The growth of the third sector in recent years has been associated with both economic development and the growth of democracy. There have been increasing demands for social-service provision. This means that a high proportion of employment in Spain ensued in the nonprofit area. The nonprofit sector was characterised by some large third-sector organisations such as ONCE (for the blind), Caritas (a Catholic-based organisation) and Red Cross (a care organisation) (Ruiz Olabuenaga 2000).

The Spanish third sector in particular has developed more strongly in recent years. The increased volume of activity of nonprofit organisations is evident; also evident and significant is their growing weight in the economy and in employment generation. Sector dynamism is reflected both in the number of entities and in the development and consolidation of large organisations with high levels of professionalism. Another observable trend is the differentiation within the sector between organisations that are principally engaged in the defence of rights, the promotion of participation, awareness, etc., and organisations that opt for the provision of specialised services to certain groups usually sponsored by governments. The harmonisation of these two fronts of activity is not always easy for organisations seeking to address both challenges.

In this context, major social-action organisations face major challenges to train their professionals, to ensure the quality of management and service in order to bring their message more clearly to the public. The visibility and the requirements of transparency and accountability are more important today than ever in a time when the value of democratic legitimacy of social organisations must be placed against increasing competition from the profit sector in the provision of many services in the social area. There is also a need to strengthen the demo- 
cratic legitimacy in order to promote a better connection between the formal organisation and its social base. It is necessary to go beyond the joint cooperation mechanisms that generate effective synergies between different organisations. It is important to demonstrate the ability to have a positive dialogue in the discussion of major public policies.

Relations with financial institutions, whether government or private enterprises, which increasingly devote resources to social investment, are a delicate area. Traditional practices are no longer seen as the most effective way to face the future. Quality, efficiency, and transparency are extremely important, since a private donor will be unlikely to donate to an organisation that cannot guarantee that donations will be used towards a social contribution. Over time, there is also the opportunity to develop more stable relations orientated towards compliance rather than bureaucracy.

The religious setting of Spain is a significant factor. It is no coincidence that the University Abat Oliba, a college with Catholic ideology, offers a master's degree in communication management for the social and solidarity economy. The political history of Spain has also had its impact upon the general development of the third sector. The long period under Franco was associated with a strong support of the church and equally a lack of support for social movements seen as a threat to the regime. Post-Franco, the social economy and co-operative sector has seen a revival with examples, such as Mondragon in the Basque Country, the largest Spanish cooperative group of 170 social enterprises, taking a strong lead.

As a consequence, the master's programmes found at Spanish universities typically have a focus upon the social economy and co-operatives. Consequently, the subjects studied are often related to economics and business-related subjects. The focus is thus on a social-economy education with a business orientation. The University of Valencia Master in Social Economy programme, for example, offers the following subjects: "Economics, law, tax, accounting, business, strategy, commerce, human resources, finance, etc., for the different kinds of organisations that make up the Social Economy. Students can choose between two specialties: A specialty in cooperatives and labour and a specialty in nonprofits" (IUDESCOOP 2012). Along with masters which are dedicated to the social economy there are master's degrees dedicated to international cooperation from different areas:

1) Masters in International Cooperation to professionalise people who are involved in international projects. The students of these Masters are younger and they want to work in professional social activities in other countries.

2) Masters in Humanitarian Cooperation focused on participation in projects related to peacekeeping missions. This type of Master is taken by professionals (doctors, architects, teachers etc.) who want to acquire knowledge to participate as volunteers in humanitarian projects. These masters are performed by means of both in-person classes and e-learning. 
Finally there are Masters in Management of Foundations and Associations providing essential training to practise as a professional in the field of nonprofit organisations like foundations, associations, etc. This type of master is aimed at those involved directly or indirectly in the management and advisory board of foundations and associations.

\subsection{The case of the United States}

The need for thoughtful, well-educated leaders in nonprofits, advocacy and philanthropy in the US is growing: nonprofits employ around $10 \%$ of the US workforce (Salamon et al. 2013). With nearly 2 million nonprofits in the US representing over $\$ 1$ trillion in revenue and $\$ 4$ trillion in assets (Roeger et al. 2012), there is a clear and growing demand for courses and programmes that equip students with the knowledge and hands-on experience needed to succeed in careers in foundations, economic development, the arts, the environment, and across the social sector. In line with this growing demand, we see an increasing number of programmes and enrolled students in related degrees at both undergraduate and graduate levels.

According to the NASPAA 2011 programme almanac, and detailed in Table 5 below, there are over 296 US-based degree programmes at NASPAA member institutions in public administration, public policy or public affairs, which enrolled over 15,623 students during Fall 2010. Of these respondent programmes, $82 \%$ offer MPA degrees, making this the most popular degree of the surveyed programmes. Indeed, over 9,799 students received their post-graduate degree in these programmes in the 2009-2010 academic year, which represents a $24 \%$ increase in degrees awarded since the 2001-2002 academic year.

Table 5

Number and types of US graduate programs

\begin{tabular}{|l|c|}
\hline Master of Public Administration & 136 \\
\hline Master of Public Policy & 20 \\
\hline Master of Public Affairs & 8 \\
\hline Executive Master & 20 \\
\hline Other Master Programs & 43 \\
\hline Offering Joint Degrees & 69 \\
\hline Total Graduate Programs & 296 \\
\hline
\end{tabular}

Source: NASPAA 2011

Currently there are 105 US universities offering graduate concentrations in Nonprofit Management Education (NME; see Mirabella 2007). The proliferation of NME programmes also appears to be a recent phenomenon with three-quarters of the existing programmes coming into existence within the last twenty years (Mi- 
rabella 2007 and O'Neill 2005). Furthermore, an increasing number of institutions are offering graduate courses in NME, among those universities, from 1996-2006, there was a $25 \%$ increase (Mirabella 2007).

The NASPAA 2011 survey also includes information about undergraduate courses in public administration, nonprofit management and health management. In fact, 76 (or $46 \%$ ) of responding schools offer courses in nonprofit management at the undergraduate level. Additionally, a web survey for this paper found 13 universities offering at least one undergraduate degree, certificate or minor in nonprofit studies, nonprofit leadership, nonprofit management, nonprofit administration or philanthropy studies. In stark contrast to the programmes and centers of social enterprise or social entrepreneurship (described below), the vast majority of schools offering undergraduate programmes and courses related to nonprofit studies house these courses within schools of public policy, public affairs, arts and sciences or general studies ( 12 of 14, or $86 \%$ ). Furthermore, a total of 72 degrees, certificates and minors were identified in disciplines closely related to public affairs and nonprofit studies.

Learning outcomes for undergraduate programmes in nonprofit studies generally include (1) an acquired understanding of the impact of the nonprofit sector on the development and implementation of public policy, (2) a bundle of professional skills appropriate for careers in the field including grant writing, resource development and programme evaluation, and (3) an externship or internship experience in the social sector.

\subsection{SE centers internationally}

The emergence of social entrepreneurship has planted the seeds for an increasing number and variety of educational activities related to the field. A key learning outcome of social entrepreneurship education is the development of skills and acquisition of knowledge to mobilise resources from various institutional spheres (Seelos et al. 2011). Pache and Chowdhury (2012) emphasise that while social entrepreneurs engage in activities similar to all entrepreneurs, the context of their work is different and therefore requires an education that brings to bear distinctions and differences of three logics: social welfare, commercial and public sector. However, in spite of this, the overwhelming majority of social entrepreneurship/enterprise education programmes are based in business schools, with a core education around the institutional logic of the commercial sphere.

A forthcoming book chapter (Rahman and Tekula 2013) includes an analysis of 28 staffed, focused Social Enterprise/Entrepreneurship specific programmes or Centers internationally (see Table 6 below for details). This list, which does not include degree programmes but actual operating institutions within universities, includes 21 US-based centers, three Canadian Centers, and one each in the UK, France, Singapore and Israel. The overwhelming majority of these centers/pro- 
grammes operate within a business school. In 2008-2009 alone, these centers/programmes sponsored over 140 courses (Rahman and Tekula 2013). In addition to this group of focused, staffed centers or programmes, the 2011 Ashoka Social Entrepreneurship Teaching Resources Handbook (Brock 2011) lists 54 programmes, majors, minors and certificates in social enterprise or entrepreneurship and 350 professors teaching or researching social entrepreneurship. This list includes faculty across 35 countries. Still, even in Brock's more inclusive lists, we see that 48 of the programmes she identifies are in the US.

Table 6

Higher education in social entrepreneurship (SE)/enterprise

\begin{tabular}{|l|c|c|c|c|c|c|}
\cline { 2 - 7 } \multicolumn{1}{l|}{} & Globally & US & UK & Spain & France & Source \\
\hline $\begin{array}{l}\text { Schools with Programs, } \\
\text { Majors, Minors and } \\
\text { Certificates }\end{array}$ & 78 & 48 & 7 & 2 & 1 & Brock 2011 \\
\hline $\begin{array}{l}\text { Related centers and } \\
\text { programs }\end{array}$ & 54 & 35 & 5 & 1 & 0 & Brock 2011 \\
\hline $\begin{array}{l}\text { Dedicated, staffed } \\
\text { centers and programs }\end{array}$ & 28 & 21 & 1 & 0 & 1 & $\begin{array}{l}\text { Rahman and } \\
\text { Tekula 2013 }\end{array}$ \\
\hline Institutions teaching SE & 148 & & & & & Brock 2008 \\
\hline Faculty teaching SE & 500 & & & & & Brock 2011 \\
\hline
\end{tabular}

\section{Conclusions}

As the public sectors of many countries come to terms with the implications of major challenges from reduced budgets and changes in the nature of public sector employment, it is appropriate to reflect on the nature of nonprofit education and consider it in the context of management and business education in the public and private sectors. Until now, published research on nonprofit programmes in higher education has typically been focused on individual countries or types of programmes. Herein we have reviewed the background of management education and compared university-level nonprofit education in the United Kingdom, Spain and the United States. We found that the number and types of academic programmes appear relatively aligned with both the size of the sector and the sector function in each country. Still, several interesting trends were uncovered.

Whilst the USA has indeed seen a significant growth in programmes, this trend has not found similar echoes in the UK or in Europe. The number of publicly prominent master's courses (i.e. those listed by specialist course search engines) is modest. Several significant providers in the UK have ceased to offer sector-focused programmes, with the London School of Economics being perhaps the most visible 
one to cease. In contrast to the UK, in the USA there has been a significant expansion of nonprofit management undergraduate programmes with a (rough) doubling of the growth of such programmes between 1996 and 2006; it is worthy of comment that only a few of such programmes were found in business faculties - the highest number were in arts and human sciences (Dolch et al. 2007).

The three countries studied here have varying degrees of exposure to the explosion of higher educational programmes in the emerging fields of social enterprise and social entrepreneurship. The United States has by far the greatest number of academic offerings in this arena, yet considering the size of this sector in the United Kingdom and Spain, we may see further development in these two countries. There is certainly room to expand upon the findings of this paper. In particular, future research may expand and build upon our work by comparing the tertiary education in the specific countries included in the Johns Hopkins studies of global civil society (Salamon 2013) to uncover trends and analyse the sufficiency of nonprofit education for each included country. International focus of nonprofit education is also due for analysis. In particular, we wonder if countries may be too insular in their nonprofit education. In other words, are adequate courses of study available to students who will become future leaders of international non-governmental organisations? And finally, considering that many of the current and potential students in nonprofit education are working at least part-time in the sector, we are keen to understand the availability of online learning in the area of nonprofit education.

\section{References}

Association of MBAs. Available at www.mbaworld.com/index.php?option=com_co ntent\&view=article\&id=109\&Itemid=124 (last accessed 24 August 2009).

Ball, Stephen J. and Carolina Junemann. 2012. Networks, New Governance and Education. Bristol: The Policy Press.

Bennington, John, Jean Hartley, J. C. Ry Nielsen and Ton Notten. 2008. "Innovation, Design and Delivery of MPA Programmes for Public Leaders and Managers in Europe." International Journal of Public Sector Management 21(4), 383-399.

Booth, Chris and Michael Segon. 2009. "A Leadership and Management Practice Development Model." International Review of Business Research Papers 5(2), 19-41.

Brock, Debbie D. 2011. Social Entrepreneurship: Education Resources Handbook. Arlington, VA: Ashoka Global Academy for Social Entrepreneurship. 
Brock, Debbie and Susan Steiner. 2009. "Social Entrepreneurship Education: Is It Achieving the Desired Aims?" Paper presented at the United States Association for Small Business and Entrepreneurship Conference, January 2008, San Antonio.

Brock, Debbie D. 2008. Social Entrepreneurship Teaching Resources Handbook. Arlington, VA: Ashoka Global Academy for Social Entrepreneurship.

Broucker, Bruno. 2007. "Measuring transfer of Public Management Programmes: The Learning Transfer System Inventory in the Belgian federal administration." Paper presented at the European Group of Public Administration, September 2007, Madrid.

Broucker, Bruno 2008. "Transfer of achieved managerial and leadership competencies in the Belgian federal administration." Paper presented at the European Group of Public Administration, September 2008, Rotterdam.

Broucker, Bruno and Annie Hondeghem. 2006. "The Effectiveness of Educational Programmes in Public Management." Paper presented at the European Group of Public Administration, September 2006, Milan.

Cepiku D., (2008), "Fonti e strumenti di misurazione della Pubblica Amministrazione: Un'analisi a livello internazionale", in RIREA: Rivista Italiana di Ragioneria E di Economia Aziendale, Vol. 108, Fascicolo 7/8, pp.536-551.

Cepiku D., (2008), "Managerial implications of local government networks: evidence from the Lazio.

Region" in Grossi G., Mussari R., Reichard C. (eds.), Local governance and its impact on public service management, CEDAM, Collana di Studi di ragioneria e di economia aziendale, Padova.

Cepiku, Denita, Marco Meneguzzo, and Mariastefania Senese. Innovations in Public Management and Governance in Italy. Roma: Aracne, 2008. Chappelet, J.L. 2009. "WOTPA: An Observatory of Teaching in Public Affairs." Presentation to the Teaching Panel at the European Group on Public Administration, September 2009, Malta.

Chell, Elizabeth, Katerina Nicolopoulou and Mine Karatas-Ozkan. 2010. "Social Entrepreneurship and Enterprise: International and Innovation Perspectives." Entrepreneurship and Regional Development 22(6), 485-493.

Coxhead, Francis et al. 2010. "New Development: Adapting University Education for Changing Expectations of Public Service Leaders and Managers: Guidance for Designing and Delivering." Public Money \& Management 30(3), $138-142$. 
Dacko, Scott G. 2006. "Developing the Top Five Skills Within an MBA Programme: Implications for Management Educators." International Journal of Management Education 5, 21-31.

Davis, Susan and Marina Kim. 2007. Social Entrepreneurship Faculty Directory: Your Guide to Professors Teaching and Researching Social Entrepreneurship. Arlington, VA: The Ashoka Global Academy for Social Entrepreneurship.

Dolch, Norman, Marvin Ernst, John E. Mclusky, Roseanne M. Mirabella and Jeffery Sadow. 2007. "The Nature of Undergraduate Nonprofit Education: Models of Curriculum Delivery." Nonprofit and Voluntary Sector Quarterly 36(4) (Supplement), 28S-50S.

Donnelly-Cox, Gemma and Sioban McGee. 2007. "Institutionalizing Support from Non Profit Management Education: Developing a Case for State Investment." Nonprofit and Voluntary Sector Quarterly 36(4) (Supplement), 136S-147S.

EDIS, Sociological Research Unit, SA. 2012."Anuario Del Tercer Sector De Acción Social En España." 2012 [editar]. Available at http://www.fundacionluisvives. org/ (last accessed 20 October 2012).

Esteves, Joaquim and Enrique Alvarez. 2006. "Public Administration Teaching: compared study of Portugal and Spain." Paper presented at the European Group of Public Administration, September 2006, Milan.

European Economic and Social Committee. 2013. "Spain: Paid Workforce." Weblog post. - Vita.it. N.p., n.d. Web. 02 Oct. 2013. Ferlie, Ewan. 1996. The New Public Management in Action. Oxford: Oxford University Press.

Herbert, Ian, John Joyce and Trevor Hassall. 2008. "Maintaining Alignment in Management Education: The Potential for Drift in Assessment." International Journal of Management Education 7(2), 21-31.

Herman, Robert D. and David O. Renz. 2007. "Nonprofit Management Alumni Knowledge, Skills, and Career Satisfaction in Relation to Nonprofit Academic Centers Council Curricular Guidelines: The Case of One University's Master's of Public Administration Alumni." Nonprofit and Voluntary Sector Quarterly 36, 98S-109S.

Higher Education Statistics Agency. 2013. "Table 0" - All students by institution, mode of study, level of study and domicile 2008/09. Available at hesa.ac.uk/ (last accessed 2 Oct. 2013).

Howorth, Carole, Susan Smith and Caroline Parkinson. 2012. "Social Learning and Entrepreneurship Education." Academy of Management Learning and Education 11, 371-389.

Institut Universitari d'Economia Social I Cooperativa. 2012. Available at http:// www.iudescoop-formaempleo.es (last accessed 20 October 2012). 
Kickul, Jill, Christine Janssen-Selvadurai and Mark D. Griffiths. 2012. "A Blended Value Framework for Educating the Next Cadre of Social Entrepreneurs." Academy of Management Learning \& Education 11(3), 479-493.

Kiisla, Aet. 2009. "Challenges of Local Government Education in a Small Country's Multi-ethnic Territory. The Case of Estonia." Paper presented at the European Group of Public Administration, September 2009, Malta.

Kolisnichenko, Natalya and Allan Rosenbaum. 2007. "Building a New Democracy in Ukraine: The Unacknowledged Issue of Ethnic and Linguistic Diversity in Public Administration Education and Training." Paper presented at the European Group of Public Administration, September 2007, Toulouse.

Knowles, Louise and David Hensher. 2008. "The Postgraduate Business Curriculum: The Frontline in the War Between Professionalism and Academic Irrelevance." International Journal of Management Education 4(3), 31-39.

Kotchegura, A. 2009. "Advanced Programme in Public Administration." Presentation at the European Group of Public Administration, September 2009, Malta.

Lawrence, Thomas, Nelson Phillips and Paul Tracey. 2012. "Introduction: Definitions and New Directions in Educating Social Entrepreneurs and Innovators." Academy of Management Learning \& Education 11(3), 408-408.

Lethbridge, J. 2009. "Promoting Public Service 'Ethos.' Presentation at the European Group of Public Administration, September 2009, Malta.

Lumpkin, G. T. and Jerome A. Katz. 2011. "Social and Sustainable Entrepreneurship." Advances in Entrepreneurship, Firm Emergence and Growth 13, 175-200.

MacFarlane, Bruce and Laurie Lomas. 1999. "Stakeholder Conceptions of Quality in Single Company Management Education." Quality Assurance in Education $7(2), 77-84$.

Mandell, Myrna. 2009. "The Importance of a New Kind of Learning in Collaborative Networks." Paper presented at the European Group of Public Administration, September 2009, Malta.

Matei, Lucica. 2009. "Bologna Changes in MA Degree Programmes: Convergence of the Public Administration Programmes in South-Eastern Europe." Paper presented at the European Group of Public Administration, September 2009, Malta.

Maravic, Patrick von and Eckhard Schroter. 2007. "Improving Administrative Performance? How High Hopes of Diversity May Be Dashed in the Public Sector." Paper presented at the Academy of Management, August 2012, Boston. 
Meijs, Lucas C. P. M. and Jeffrey L. Brudney. 2007. “The Other Side of the Coin': What Do Business Schools Teach the Typical Business Undergraduate About the Non Profit Sector? A Case Study from the Netherlands." Nonprofit and Voluntary Sector Quarterly 36(4) (Supplement), 80S-97S.

Mikulowski, Witold. 2008. "Innovation in the Public Sector: Between Tradition and Modernity.

Teaching Standards of Public Administration Programs in Poland" Paper presented at the European Group of Public Administration, September 2008, Rotterdam.

Mikulowski, Witold. 2009. "Public Administration Degree Programs of General Higher Education System versus Non Degree, Postgraduate and In-service Training Programs - the Polish Case." Paper presented at the European Group of Public Administration, September 2009, Malta.

Miller, Toya L., Curtis L. Wesley and Denise E. Williams. 2012. "Educating the Minds of Caring Hearts: Comparing the Views of Practitioners and Educators on the Importance of Social Entrepreneurship Competencies." Academy of Management Learning \& Education 11(3), 349-370.

Mintzberg, Henry. 2004. Managers Not MBAs: A Hard Look at the Soft Practice of Managing and Management Development. London: Berrett-Koehler.

Mirabella, Rosanne M. 2007. "University Based Educational Programs in Non Profit Management and Philanthropic Studies: A 10 Year Review and Projections of Future Trends." Nonprofit and Voluntary Sector Quarterly 36(4) (Supplement), 11S-27S.

Mirabella, Rosanne M. and Dennis R. Young. 2012. “The Development of Education for Social Entrepreneurship and Nonprofit Management: Diverging or Converging Paths?" Nonprofit Management and Leadership 23(1), 43-57.

Mottner, Sandra and Walter Wymer. 2011. "Nonprofit Education: Course Offerings and Perceptions in Accredited U.S. Business Schools." Journal of Nonprofit \& Public Sector Marketing 23(1), 1-19.

Murdock, Alex. 2009. "MBA/MPA/NPO-Masters Crossovers and Differences." Paper presented at the European Group of Public Administration, September 2009, Malta.

Murdock, Alex and Chrissie Oldfield. 2010. "The Public Management Masters in the broader management education environment." Paper presented at the European Group of Public Administration, September 2010, Toulouse. 
NASPAA. 2011. Program Almanac, based on NASPAA's Fall 2010 Enrollment and Academic Year 2009-2010 Degrees Awarded Survey. Washington, D.C. Available at http://67.199.57.12/naspaa/DataCenter/Almanac/Almanac2010.cfm (last accessed 2 Oct. 2013).

National Council for Voluntary Organisations. 2012. The UK Voluntary Sector Almanac. London: NCVO.

Nemec, Juraj, Spacek, D., Suwaj, P., Modrzejewski, A. 2009. “Does Public Administration Higher Education in CEECs Reflect Demands Created by NPM Reforms?" Review of Economic Perspectives 11(3), 124-240.

Norell, P. O. 2008. "New Challenges to the Swedish-Norwegian MPA: Time for Reconsideration?" Paper presented at the European Group of Public Administration, September 2008, Rotterdam.

Norell, P. O. 2009. "What did you learn in MPA this year? Evaluaing the SwedishNorwegian MPA Programme." Paper presented at the European Group of Public Administration, September 2009, Malta.

Oldfield, Chrissie. 2007. "Making Equality and Diversity Mainstream in Public Management Education." Paper presented at the European Group of Public Administration, September 2007, Madrid.

Nygard, Claus, and Pia Bramming. 2008. "Learning Centred Public Management Education." International Journal of Public Sector Management 21(4), 400-416.

O’Neill, Michael. 2007. “The Future of Non Profit Management Education.” Nonprofit and Voluntary Sector Quarterly 36(4) (Supplement), 169S-176S.

O’Neill, Michael. 2005. "Developmental Contexts of Non Profit Management Education." Nonprofit Management and Leadership 16(1), 5-17.

Pache, Anne-Claire and Imran Chowdhury. 2012. "Social Entrepreneurs as Institutionally Embedded Entrepreneurs: Towards a New Model for Social Entrepreneurship Education." Academy of Management Learning and Education 11(3), 494-510.

Palmer, Paul. 2006. "The Grit in the Oyster: The Development and Future of NonProfit Education in the UK." Published paper given at NCVO Researching the Voluntary Sector Conference in 2006.

Palmer, Paul and Mariana Bogdanova. 2008. "The British Are Not Coming! Higher Education and the Nonprofit Sector." Nonprofit Management and Leadership 19(1), 79-99.

Paton, Rob. 2008. "Comment on: The British Are Not Coming! Higher Education and the Nonprofit Sector." Nonprofit Management and Leadership 19(1), 101-105. 
Paton, Rob, Jill Mordaunt and Chris Cornforth. 2007. "Beyond Nonprofit Management Education: Leadership Development in a Time of Blurred Boundaries and Distributed Learning." Nonprofit and Voluntary Sector Quarterly, 36(4) (Supplement), 148S-162S.

Pedersen, Dorthe and Jean Hartley. 2008. "The Changing Context of Public Leadership and Management: Implications for Roles and Dynamics." International Journal of Public Sector Management 21(4), 327-339.

Quinn, Brid. 2009. "Adding value(s) to practice and pedagogy." Paper presented at the European Group of Public Administration, September 2009, Malta.

Quinn, Brid and Grete Wennes. 2008. "Mind Sets, Mirrors and Mid-career Education: The Why, What and How of Promoting Critical Inquiry Among Managers." International Journal of Public Sector Management 21(4), 353-367.

Rahman, Noushi and Rebecca Tekula. 2013. A Replicable Evaluation Method of Social Entrepreneurship Centers and Programs. Pate, Larry; Wankel, Charles (Eds.), Emerging Research Directions in Social Entrepreneurship. Dordrecht: Springer, Forthcoming.

Raines, John W. and Anne Rubienska. 2008. "The Art and Dilemmas of Assessment: European Perspectives on the Assessment of Practitioner Learning and Development Through Masters Level Programmes in Public Management." International Journal of Public Sector Management 21(4), 417-437.

Richter, Andreas W., Michael A. West, Rolf Van Dick and Jeremy F. Dawson. 2006. "Boundary Spanners' Identification, Intergroup Contact and Effective Intergroup Relations." Academy of Management Journal 46(6), 1252-1269.

Roeger, Katie L., Amy Blackwood and Sarah L. Pettijohn. 2012. The Nonprofit Almanac 2012. Washington, D.C.: Urban Institute.

Ruiz Olabuenaga, José Ignacio. 2000. Bilbao, La Cuidad Soñada I \& II. Bilbao Bizkaia Kutxa, 2000. Print.

Ruiz Olabuenaga, José Ignacio. 2002. El sector no lucrativo en España: una vision reciente. Place: Fundación BBVA Research Project.

Salamon, Lester M., S. W. Sokolowski, Megan A. Haddock and Helen S. Tice. 2013. The State of Global Civil Society and Volunteering. John Hopkins University: Center for Civil Society Studies.

Santiago, P., J. Brunner, G. Haug, S. Malo and P. di Pietrogiacomo. 2009. OECD Reviews of Tertiary Education: Spain. Paris: OECD.

School for Social Entrepreneurs (SSE). 2012. http://www.the-sse.org/ (last accessed 20 October 2012). 
Seelos, Christian, Johanna Mair, Julie Battilana and M. Tina Dacin. 2011. "The Embeddedness of Social Entrepreneurship: Understanding Variation Across Local Communities." IESE Business School, University of Navarra. Working Paper.

Simón-Moya, Virginia, and Lorenzo Revuelto-Taboada. 2012. "A Comprehensive Understanding of Social and Sustainable Entrepreneurship." Management Decision 50(4), 744-748.

Smith, Isaac H. and Warner P. Woodworth. 2012. "Developing Social Entrepreneurs and Social Innovators: A Social Identity and Self-Efficacy Approach." Academy of Management Learning \& Education 11(3), 390-407.

StudyPortals. 2013. "Search Portal for Masters Programs." Available at http://www. mastersportal.eu/study-options/268927077/public-administration-unitedkingdom.html (last accessed 2 Oct. 2013.).

Tekula, Rebecca. 2008. Doctoral Programs in Public Administration in the United States: A Survey of the Current Curricula 2007/2008. Berne, Switzerland: Pôle National en Administration Publique.

Thiru, Yaso. 2011. "Social Enterprise Education: New Economics or a Platypus?" Advances in Entrepreneurship, Firm Emergence and Growth 13, 175.

Tschirhart, Mary, Kira K. Reed, Sarah J. Freeman and Alison L. Anker. 2008. "Is the Grass Greener? Sector Shifting and Choice of Sector by MPA and MBA Graduates." Non Profit and Voluntary Sector Quarterly 37(4). 668-688.

United Kingdom, H. M. Treasury, Cabinet Office. 2007. The Future Role of the Third Sector in Social and Economic Regeneration: Final Report. Online: The Stationery Office.

United States of America. U.S. Department of Commerce. U.S. Census Bureau. 2013. Higher Education: Institutions and Enrollment. U.S. Census Bureau. Available at http://www.census.gov/ (last accessed 3 July 2013).

Upsall, Daryl. 2013. Spain: Opportunity, Growth and Challenges for the Third Sector. Available at resource-alliance.org (last accessed 2 Oct. 2013).

Van Der Meer, Frans-Bauke. 2008. "Interaction between demand and supply in mid-career PA teaching." Paper presented at the European Group of Public Administration, September 2008, Rotterdam.

Van Der Meer, Frans-Bauke and Arthur Ringeling. 2007. "Education strategies in post-experience Public Administration masters programs." Paper presented at the European Group of Public Administration, September 2007, Madrid.

Vesper, Karl H. and William B. Gartner. 1997. "Measuring Progress in Entrepreneurship Education." Journal of Business Venturing 12, 403-421. 
Walsh, Roberta. 2006. "Exploring the Case Study Method as a Tool for Teaching Public Administration In a Cross-national Context: Pedagogy in Theory and Practice." Paper presented at the European Group of Public Administration, September 2006, Milan.

Weber, J. M. 2012. "Social Innovation and Social Enterprise in the Classroom: Frances Westley on Bringing Clarity and Rigor to Program Design." Academy of Management Learning \& Education 11(3), 409-418.

Wilson, David A. 2007. "Tomorrow, Tomorrow and Tomorrow: The Silent Pillar." Journal of Management Development 26(1), 84-86.

Young, Dennis. 1999. "Nonprofit Management Studies in the United States: Current Developments and Future Prospects." Journal of Public Affairs Education 5, $13-24$. 